\title{
新型绿色节能技术在建筑工程施工中应用探讨
}

\author{
葛中良 ${ }^{1}$ 邢启芳
}

1 莒县兴汇建材有限公司 2 日照市沭锦矿业有限公司

DOI:10.32629/btr.v3i5.3107

[摘 要] 绿色节能建筑是现代建筑的主要特征,绿色节能施工技术的实际应用可以有效改善传统施工造成的污染问题和水资源浪费。同时,在 建筑的关键环节充分运用绿色节能技术, 实现绿色节能建筑, 为人们创造宜居舒适的生活环境。本文基于新型绿色节能技术在建筑工程施工中的 应用分析。

[关键词] 绿色节能技术; 建筑工程施工；应用

\section{1 新型绿色节能技术基本特征}

新型绿色节能技术具有实用性强, 有益于环保, 能耗低, 价格低廉, 对 人体健康伤害小乃无害的特点。它在建筑工程项目中的广泛应用可以减少 能源消耗, 减少废物和废料的排放, 在一定程度上减少对环境的污染, 并及 时加以保护。同时, 新型绿色节能环保技术采用绿色环保材料, 可以有效减 少对人体健康的危害, 为人类生活提供安全绿色环境。新型绿色节能技术 的应用, 是建筑工程项目可持续发展理念的具体体现, 是建筑行业构建绿 色生态社会的重要手段之一。

\section{2 绿色节能技术在建筑工程施工中的应用}

2. 1 不断推进和探索新型节能设计方法

在整个建筑工程中, 首先, 应针对建筑物的体型和建筑群体的组合进 行合理的设计, 使其能够适应不同的环境和气候。通常, 建筑物体型系数越 小, 热量交换量越少, 建筑的节能效果越好。其次, 在建筑物的平面设计中, 夏季的穿堂风和冬季的全明房在建筑节能中起着重要的作用。合理的平面 布置有利于在通风状态下达到预期的效果, 确保节能效果, 解决因使用空 调而造成的空气质量差的问题。

2. 2 对土地资源的控制使用情况分析

随着经济的不断发展, 对于土地资源的需求也在增加, 人口在增加, 城 市化进程也在加速, 我国的土地资源处于短缺状态。所以, 在建筑施工过程 中, 必须积极控制施工用地, 运用绿色节能技术, 在施工过程中, 首先要做 好土地勘测工作, 认真分析。在施工过程中, 必须合理有效地利用土地资源, 使土地价值最大化, 厉行节约, 保护和利用土地资源。

2. 3水循环技术在施工工程中的利用

众所周知, 当今全球水资源缺乏, 水非常紧张, 在我国, 缺水问题更 加严重。所以, 有必要在施工过程中积极合理地运用绿色节能技术和水 循环技术。在当今的传统建筑过程中,一次性排水系统将被设计为二次 或多次循环利用系统, 以实现水循环, 但是实际上, 这是不正确的, 因为 在此过程中, 无法区分生活污水和废水, 最后将所有这些水送至统一处 理, 但是实际上, 施工过程中产生的污水不需要特殊处理, 只要经过简单 的处理后就能使用 (如用到施工工具的清洁和绿化)。所以, 在使用水循 环技术的前提下, 有必要区分污水和废水两部分, 提升水资源利用效率, 还可以满足环保要求。

2.4 光照节能技术的应用分析

对于建筑物, 节能务必要关注到顶面。建筑物的顶面会受到多种因素 的影响, 其中最常见的是自然影响, 风吹日晒等, 不认真控制顶面温度的 工作会降低居住者的舒适度。为了解决这个问题, 有必要充分利用绿色 技术。首先, 在施工期间使用具有良好保温效果的材料来阻挡内部和外部
环境。其次, 采用顶面种植技术。在防水的情况下, 在顶面栽种植物, 不仅 能绿化还以环保, 一举两得。第三, 充分利用遮阳板控制室内热量, 改善室 内环境。最后, 在建筑物的顶层建立太阳能热水系统, 能满足冬季取暖需求, 达到生态节能的目的, 充分利用好这些技术是绿色节能技术的意义。

2.5 新型绿色能源的使用

在建筑施工中, 使用的醇基液体燃料主要是甲醇, 使用这种新型液体 燃料可以提升燃料使用效率, 调查显示, 与柴油相比, 甲醇燃料的消耗量可 达到柴油的1. 3倍。所以, 甲醇排放量低, 并且具有来源广泛的优势, 广泛用 于建筑施工中。另外, 许多建筑人员现在已经意识到可再生能源的价值, 在施工过程中使用风力, 地能和水能等资源可以减少资源消耗, 实现环境 和经济效益的统一。

2.6 可再生能源的利用

在建筑施工过程中使用的可再生能源主要有两种, 即太阳能和风能。比 如, 通过在普通地板中使用特殊的储能太阳能相变材料, 可以形成太阳能存 储相变地板。在冬季, 太阳能相变地板可以储存白天辐射的太阳能, 而夜间 相变地板可以释放白天储存的太阳能为室内进行供暖。另外, 为了向室内 提供新鲜空气, 设计师将在地板上设计一些小孔, 以将风传到楼层中。与普 通天花板相比, 新型地板可以直接送风, 孔板送风系统将隐藏在地板下, 并 连接到天花板上的二氧化碳检测设备, 根据二氧化碳的量计算房间中的人 数, 然后系统会相应地调整风量。

2.7 在建筑墙体保温施工中, 可以利用新型绿色节能技术

在工程建筑的施工过程中, 墙体的外围结构必须采用保温技术, 其良 好的热性能可以满足建筑施工中绿色环保理念的实施。外围墙建设是建筑 项目施工内容中不可或缺的组成部分, 在工程墙的混凝土施工过程中, 应 选择导热系数小的火山灰混凝土浇筑。

\section{3 结束语}

随着环境的恶化,环境保护问题已成为国家和个人高度重视的问题。在 建筑施工中, 绿色节能建筑技术还可用于改善当前建筑施工中的污染问题, 并将对居民居住环境的负面影响降至最低。所以, 加强绿色节能施工技术 的应用研究对促进建筑业的长远发展具有重要意义。

\section{[参考文献]}

[1]王龙.新型绿色节能技术在建筑工程施工中的应用 [J].建材与装 饰,2020(10):30-31.

[2]王晓静.绿色施工技术在建筑工程施工中的应用 [ J ] . 江西建 材,2019(12):112+114.

[3] 吴顺利.浅谈建筑工程施工中绿色节能技术的应用 [J].建材与装 饰,2019(33):8-9. 